\title{
映像情報の付与が音声情報の理解に及ぼす影響
}

\author{
音声情報と映像情報の理解と印象の比較による検討 \\ $\bigcirc$ 松本絵理子 ${ }^{1}$ \\ (1 神戸大学国際文化学研究科) \\ キーワード：情報理解、注意、印象
}

\section{An analysis of input modality effects on recognition and impression of information. Eriko MATSUMOTO ${ }^{1}$ \\ ( ${ }^{1}$ Graduate School of Intercultural Studies, Kobe Univ.)}

Key Words: information comprehension, attention, impression

\section{目 的}

テレビニュースではアナウンサーが原稿を読み上げる映像 が映し出されることがしばしばあるが、読み上げる情報の記 憶や理解にこの映像は促進的に働くのだろうか。音声を発話 する映像と音声の知覚に関する先行研究では、音声情報の知 覚がどのような口の動きで発話されるかが影響を受けること が知られており（McGurk \& MacDonald, 1976）、音声とそれを 発話する映像が併せて呈示されることが、内容の知覚過程に 相補的な役割を担っていると考えられる。しかし、一定以上 の長さを持つニュース文章などを視聴する場合に、アナウン ス映像が付与されることは、その内容の認知過程にどのよう な影響を及ぼすかについては、不明な点が多い。Pezdek \& Stevens (1984)では、5 歳の子供を対象に子ども番組のビデオ クリップを用いて、映像と音声、映像のみ、音声のみの条件 に加え、映像と音声の内容が不一致になっている条件を設定 し、それらの視聴後の理解度に関する課題と、内容の記憶に 関する課題を行っている。その結果、音声情報の理解と記憶 においては、映像が付与されている条件と音声のみの条件で、 統計的に有意な差は見られなかった。この結果から、映像が 付与されることが必ずしも音声内容の理解に対して促進され るとは言えず、音声にのみ注意を払うことにより、理解が容 易になる場合もありえるのではないかと考えられる。

Lavie(2005)は課題の負荷に応じて、課題非関連の妨害刺激 の処理が変化することを処理資源の観点から説明を行ってい る。例えば、ワーキングメモリ課題の負荷が高い場合に、妨 害刺激の効果がより高くなる背景には、認知的な処理資源が 標的となる課題処理に向けられることで、妨害刺激を制御す るための資源が枯渇し、妨害抑制が困難になると説明してい る。一定以上の長さを持つニュース文章などの情報内容を保 持し、理解寸るにはワーキングメモリの働きが必要であるが、 もし理解寸る文章の難易度が高い場合には、映像情報が併せ て呈示されることにより、内容情報を十分に処理できず、映 像情報の付与が妨害的に働く可能性も考えられる。一方で、 映像情報が加わることにより、情報に関する信頼性や安心感 といった感情的側面において効果があり、それによって理解 が促されるという可能性も考えられる。そのため、本研究で は難易度が異なるニュース文章を、音声のみと音声と映像の 両方を同時に呈示した場合における、内容の理解度と印象を 測定し、課題難易度による映像情報の付与の効果の違いにつ いて検討を行った。

$$
\text { 方 法 }
$$

実験参加者 大学学部生・大学院生 41 名（内女性 29 名、 平均年齢 21.8 歳、範囲 19 歳 -25 歳)

装置 デジタルビデオカメラ（Panasonic, NV-GS300) で、ア ナウンス映像と音声を記録した。映像と音声の制御と呈示に
はパーソナルコンピュータ（De11 Dptiplex170）とモニター (De11, 19 インチ)、ヘッドフォン (Sanwa Supply NM-HS503SV) を用いた。

実験材料 長さは同程度で内容が異なる刺激文（天気二ュー ス、経済ニュース）を 2 種類用意し、これを音声のみと映像 と音声の 2 種類の呈示方法で実験に用いた。刺激文には、400 字程度で記述されたニュース原稿を用いた。予備調査を行い、 刺激文の難易度を調整した。

手続き 実験参加者は、モニターの前に座り、ヘッドフォン を装着して刺激を視聴した。観察距離は約 $60 \mathrm{~cm}$ であった。映 像はモニター上に、視角にして $30^{\circ}$ x $22^{\circ}$ の大きさで呈示さ れた。視聴時間は約 1 分 30 秒で、音声のみの条件では、グレ 一の画面の状態で音声を視聴した。視聴後に、理解度テスト に回答し、最後に印象に関する評定を行った。理解度テスト は各々の刺激文に対して 5 問ずつ用意し、3つの選択肢から 正答を選ぶように教示した。併せてS D 法を用いて印象評定 も行った。理解度テスト、印象評定共に制限時間は設定しな かった。

\section{結 果·考 察}

理解度に関する $5 つ$ 質問文について、 1 問正答につき 1 点、 5 点満点で集計を行った。この結果について情報の種類（難 易度低、難易度高） $\mathrm{x}$ 呈示メディアの種類（音声のみ、音声 と映像）を被験者間要因とする二元配置分散分析を行った。 その結果、メディアの種類で主効果が有意であり $(F(1,9)=$ 5.76, $\left.p=.04, \eta^{2}=0.39\right)$ 、情報の種類は有意傾向であっ た $\left(F(1,9)=3.79, p=.08, \eta^{2}=0.29\right)$ 。交互作用は有意 ではなかった。呈示メディアの効果は有意であり、音声のみ の方が理解得点は高かった。交互作用はみられなかったこと から、情報の種類や難易度が異なる場合でも、一定程度の長 さの音声情報の理解には、映像が付与されるとむしろ妨害的 に働くことが示された。また、印象については、映像が加わ った場合にはより情緒的印象が強くなり、音声のみの場合に は信頼性や好ましさという側面が注目されやすいことが示さ れた。本研究では、理解や印象における呈示メディアの違い を検討したが、伝達する情報の質・量により、これらの結果 は異なる可能性があり、さらなる検討が必要である。

\section{引用文献}

McGurk, H. \& MacDonald, J. (1976) Hearing lips and seeing voices. Nature, 264, 23-30.

Pezdek, K \& Stevens, E. (1984). Children's memory for auditory and visual information on television. Developmental Psychology, 20, 212-218,

Lavie, N. (2005). Distracted and confused?: selective attention under load. Trends in Cognitive Sciences, 9, 75-82. 